\title{
Foreign direct investment in Mexico Determinants and its effect on income inequality
}

Carmen Guadalupe

Juárez Rivera

Universidad Politécnica de

Tulancingo

cgjuarezr@hotmail.com

Gerardo Ángeles Castro Escuela Superior de Economía, Instituto Politécnico Nacional gangeles@ipn.mx

\section{Abstract}

By conducting panel data analysis across 32 federal entities in Mexico over the period 1994-2006, this paper studies the determinants of foreign direct investment (FDI) and its effect on income inequality within and between regions. We observe that the level of development and the size of the market have a direct relationship with FDI and therefore, they tend to increase the inequality gap between regions, but there is no evidence suggesting that it creates inequality within them.

Keywords: foreign direct investment, determinants, income inequality, panel data, economic growth 


\section{Inversión extranjera en México. Determinantes y su efecto en la desigualdad del ingreso}

\section{Resumen}

A través de un análisis de datos en panel para 32 entidades federales en México durante el periodo de 1994 a 2006, este trabajo explora las determinantes de la inversión extranjera directa (IED) y su efecto sobre la desigualdad del ingreso dentro y entre las regiones. Se observa que el nivel de desarrollo y el tamaño de mercado tienen una relación directa con la IED; por lo tanto, tienden a acrecentar la brecha de desigualdad entre las regiones, pero no existe evidencia que sugiera que la IED genera desigualdad dentro de las regiones.

Palabras clave: inversión extranjera directa, determinantes, desigualdad del ingreso, panel de datos, crecimiento económico.

\section{Introduction}

The theoretical and empirical arguments on the determinants of foreign direct investment (FDI) in the relevant literature, are diverse and in some cases controversial. Beginning with the Ricardian two-factor model, which establishes that international exchange is given by the existence of comparative advantages between countries, it means that labor abundant countries most import capital, and capital abundant countries most import labor, based on the suggestion of Stopler-Samuelson neoclassical model that states that market openness increases the use of low cost, an abundant factor in developing countries, as exports and imports adjust according to the orthodox principle of comparative advantages. Hence, according to standard theory, an important determinant of FDI in developing countries is the low-cost labor and foreign investment has a distributional effect on the economy (Ghosh, 2003; Lee and Vivarelli, 2006). In this sense, less developed countries have a comparative advantage on labor and so their exchange pattern bases on wages, they are able to attract FDI from developed countries due to lower wages. Moreover, foreign investment is expected to flow towards the production of tradable goods that mainly uses the cheaper and abundant factor of the economy, while the costly and scarce factor is less used. This mechanism increases the income of the factor which is relatively most used in the export sector and is also most abundant, this factor is conventionally assumed to be unskilled labor in developing countries; by the same token, income distribution is expected to improve and eventually both countries benefit. 
Orthodox theory has found empirical support to the extent that the surge of market-oriented policies, implemented worldwide since the 1980s, has encouraged the FDI flow from developed to developing countries and one of the main reasons is the comparative advantage in terms of lower wages in the host countries (UNCTD, 1998). There is also empirical evidence that wages have increased in the regions where FDI has concentrated. On the other hand, although corporations can move to low-cost labor countries, they do not tend to move to less developed regions within a specific country (Redding and Venables, 2004; Ma, 2006), and in some cases they seek for qualified labor in relative terms (Fenestra and Hanson, 1997; Lipsey and Sjöholm, 2004), especially if the production process involved has skill-biased technology, relative to the traditional local production. This trend consequently can increase the income gap within and between regions in the host country and therefore, challenges orthodox assumptions.

Since FDI is a form of international exchange in which the main actors are Multinational Corporations (MNC), we have to remember that an enterprise's main goal is to increase earnings so they will select locations which facilitate the achievement of this (Kaya and Walker, 2009). Considering that MNC think of FDI as an exchange facilitator, alternative theories suggest additional determinants of FDI. For instance, the eclectic theory, evolved by Dunning $(1980,2001)$, integrates three interrelated concepts to evaluate the factors influencing and determining cross-border production. In its general form, the theory is also known as the OLI paradigm due to the three main concepts it involves, which are explained as follows:

(O) Ownership advantages, are firm specific characteristics, such as technology, brand name or economies of scale, that can be transferred between countries within the multinational enterprise and, they facilitate higher revenues and/or lower costs that offset the cost of operating in a foreign country, they also provide market position and operational advantages over other firms.

(L) Location advantages or country specific advantages, are important to determine the host country or the region within it, they should guarantee an efficient and profitable operation of the firm; they can be separated in two groups: The first group comprises economic and geographical features, which are related to quantity, quality and cost of, and access to, production factors, market size, access to skilled labour, distance to major markets or to the home country, and access to infrastructure, transport and communications. The second group involves political 
advantages, such as the legislation that affects the FDI regime, trade and international production.

(I) Internalization advantages comprise the options that the firm has to operate directly or indirectly in a host country, for instance, the firm can own the facilities or alternatively can licence its specific advantages to another firm, create subsidiaries abroad, enter a joint venture with another company, form alliances or sell franchises; in any case, the firm will have to, first, study the effect of the option that guarantees more benefit and less risk.

Dunning (1990) also states that FDI benefits host countries in the next five lines: 1) by enterprise efficient productivity while diminishing management costs or increasing returns from labor and/or capital; 2) trough innovation, quality improvement, or managerial estructures; 3 ) trough relocating production resources according to comparative advantages; 4) by accesing new foreign markets and 5) diminishing costs by changes on demand and supply.

On the other hand, with the pass of time, market distortions have been decreasing thanks to government's recognition of their impossibility to satisfy the demand of investment necessary for economic growth and development. Endogenous economic growth theory (Mattos, 2002), supposes that long term growth depends on the country capacity to accumulate capital, human capital and knowledge, that is the reason why governments should plan and define the accumulation level of this factors according to growth expectancies. Countries have been designing policies to stimulate private investment attraction in which FDI is included (Ros, 2004).

To conclude, orthodox theories suppose that using comparative advantages less-developed countries will increase their labor demand by attracting FDI due to cheap labor costs, MNC which are capital owners have to define their locations with the object of increasing earnings which can be possible if they establish in less developed countries with low wages. Then, scarce capital countries should attract FDI trough openness policies that will suit endogenous economic growth.

The certainty of this depends on the interest of MNC; in order to explain this we give Kojima (1973) and Markusen (1999) classifications for FDI. Kojima divides FDI basically in two types: the one that promotes trade, "trade - oriented" and the other one that inhibits trade: "not-trade-oriented". 
Under this assumption, trade-oriented FDI is the kind that seeks resources according to comparative advantages, it means that a country looks for a location to compensate for its lack of resources or labor; under this context FDI helps to build an export structure which positively contributes to international trade. On the opposite, there is the not-trade-oriented FDI. This kind tries to avoid trade barriers (qualitative and quantitative) to get a costs reduction, it looks for locations to increase the enterprise's market, it does contribute to import substitution, so it does inhibit international exchange.

Markusen and Maskus (1999), by use of the basic FDI classification of"vertical kind" and "horizontal kind", developed the "capital - knowledge kind". Definitions are as follows:

Vertical FDI is represented by firms whose production processes have been divided and located in different geographical regions according to comparative advantages. Under a vertical FDI model, multinational activity is defined by differences in countries factor endowments, this type will be relevant only when countries get different endowments and it helps for international exchange.

Horizontal FDI consists of multiple plant firms which strictly replicate their production process in every location they have. In this case, the firm is looking to supply the host country market. This type of FDI will be relevant only in similar countries, otherwise just one of them will benefit either from market size or from the difference on costs factors.

Capital-Knowledge FDI conjugates the two concepts above. In other words, it allows multinational corporations to have multiple plants and to divide geographically the production process. The capital-knowledge FDI model has two important assumptions: first, that knowledge can move internationally and second, the existence of multiproduction facilities. Under this model, FDI will be relevant in either similar countries or countries with different endowments. This type of FDI satisfies the needs of costs factors and those of bigger markets, it also provides the host country the opportunity to attract horizontal and vertical FDI.

This study is aimed at testing the significance of the economic and geographical specific advantages, as determinants of FDI across 32 local states in Mexico, over the 1994-2006 period; we do not include political determinants, as the relevant Mexican legislation is a region-invariant variable. 
If we assume that FDI brings with it economic benefits and, according to the OLI paradigm, agglomeration or level of development, in terms of infrastructure, human capital, market size, etc., are positively related to the inflow of FDI, we can infer that FDI will create inequality across regions, and can have diverse effects within regions. In this respect, this paper is also aimed at testing the effect of FDI on inequality within and between 32 local states in Mexico. The period of the study commences in 1994 because the current methodology to measure FDI across regions in Mexico started that year. This period is relevant because it incorporates the North America Free Trade Agreement (NAFTA) era, that became effective also in 1994. The paper is organized as follows: In section 2 we explain the variables, in section 3, the econometric analysis is conducted, and section 4 is the conclusion of the paper and it outlines policy.

\section{The data}

For this study, we constructed a balanced panel consisting of 224 observations, across 32 federal entities in Mexico, over 7 time observations, every two years, between 1994 and 2006. The analysis includes 5 sets of explanatory variables to study if economic and geographical advantages, across Mexican regions, are significant determinants of FDI and, to study their effect on income inequality.

The first set comprises income level variables, Gross Domestic Product (GDP) per capita and average wage in real terms, the source is Instituto Nacional de Estadística Geografia e Informática (INEGI, 2011) and Comisión Nacional de Salarios Mínimos (CONASAMI, 2011), respectively. The second set contains market size variables, GDP in real terms and population, the source is INEGI (2011) and Consejo Nacional de Población (CONAPO, 2011). In the third set we include variables to measure human capital or specialization, they are per capita government expenditure on education (INEGI, 2011) and educational attainment, the source is Secretaría de Educación Pública (SEP, 2011). The fourth set comprises variables that represent infrastructure; they are government expenditure on transport and communications per capita (INEGI, 2011a), and per capita landline telephones (INEGI, 2011). The fifth and last set contains 2 geographical location variables in relation to major markets. The first variable is constructed by taking the distance between the capital of the local state and Mexico City (the major market in the country), and it is aimed at testing if FDI is market seeking or horizontal. The second variable takes the distance between the capital of the local state and the 
closest official crossing point at the borderline with the US, and is aimed at testing if FDI is vertical or production cost-minimizing, the source is Geobytes, Inc. $(2011)^{1}$. Our dependent variable is FDI (INEGI, 2011); it is also incorporated as an explanatory variable in the inequality models. The explanatory variables are also included in the inequality models. All the per capita variables are constructed with population data from CONAPO (2011).

The dependant variable on income inequality within regions is the GINI coefficient; it is constructed with micro level data from household income surveys provided by (INEGI, 1994-2006). The dependent variable on inequality between regions is defined as follows.

$$
I_{i t}=y_{D F t}-y_{i t}
$$

where $I$ is the index on income inequality between regions, $i$ is the local state, $t$ is the time period, $y_{i t}$ is the log of per capita GDP for every local state in the time period $t, y_{D F t}$ is the log of per capita GDP for Mexico City at the time t. The variable is expressed in positive values because it takes the region with the highest GDP per capita (Mexico City) as reference. This has been used before as an index of inequality between countries by Chatterji (1992), and as an index of inequality between Mexican regions by Rodríguez-Oreggia and Costa-i-Font (2002).

\section{The econometric model}

In this section we conduct three different sets of regressions. The first set is aimed at testing the determinants of FDI. In the second and third sets studies the effect of FDI and its determinants on income inequality within and between regions respectively. All the regressions are performed in logs, in order to obtain elasticities and to be able to conduct homogeneous interpretations of the effects of the explanatory variables. Every equation is performed through five different specifications, ordinary least squares (OLS), fixed effects (FE) with group dummy variables, FE with

\footnotetext{
${ }^{1}$ Shatz and Venables (2000) argue that firms make investments in a foreign country due to 2 main reasons. The first one is to economize on tariffs and transports cost in order to better serve the local market; this type of FDI tends to locate within or close to local major markets and is called horizontal or market seeking. The second one is to reduce the cost of production factors to supply the production process with lower-cost inputs, in order to increase profits; this type of FDI tends to locate in low-cost labor regions or countries, close to the source country, and is called vertical or production cost-minimizing. In this study we consider the US as the source country because between 2000 and 2006 it provided about 96 percent of the FDI inflow to Mexico (INEGI, 2011).
} 
group and time dummy variables, random effects (RE) with cross-section error component and, RE with cross-section and time error components.

In order to select the appropriate specification, three different tests are carried out. The $F$ test examines if data are poolable, that is, if groups or time periods have the same constant; alternatively it studies if the group dummy variables or the time dummy variables are statistically significant when they are added to the pooled regression in order to turn to FE models. The null hypothesis of the $F$ test across groups is $H_{0}: \alpha_{i}=\alpha$, the null hypothesis over time is $H_{0}: \alpha_{t}=\alpha$, we also combine both null hypothesis when both group and time dummy variables are added to the OLS equation. The $F$ test can also be performed to compare different specifications, for instance, group and period effects versus group effects. In any case, if the null hypothesis is rejected, the unrestricted regression is appropriate. To test for the presence of random effects we use the Breusch and Pagan Lagrange Multiplier (LM) test (1980) based on the OLS residuals, if the null hypothesis $H_{0}: \sigma^{2}{ }_{u}$ $=0$ is true, that is, there are no random effects (individual-specific or time series error variance are cero) and therefore the classical (pooled) regression model with a single constant $\left(\alpha_{i}=\alpha\right)$ is appropriate, then the LM statistic has a distribution that is chi-squared with one degree of freedom. The Hausman test (1978) compares the coefficient estimates from the RE model to those from the FE model, the idea underlying the test is that both the RE and the FE estimators are consistent if there is no correlation between the individual or period error components and the explanatory variables $x_{k i t}$ and, therefore, they should not differ systematically. On the other hand, if the unobservable error components are correlated with any $x_{k i t}$, the RE estimator is inconsistent, while the FE estimator remains consistent. The test statistic has and asymptotic chi-squared distribution, if the null hypothesis $H_{0}$ : the two estimates should not differ systematically is rejected, the RE estimator is inconsistent and the FE model is preferred.

\section{Determinants of FDI}

Table 1 presents the regression of FDI on its determinants. When we conduct the $F$ test to compare the group and period effects specifications to the group effects equations, the results show that the restricted regressions are appropriate at the 5 percent level of significance. In contrast, the $F$ test rejects the null hypothesis when comparing the group effects equations versus the OLS regressions. This outcome suggests that the FDI functions change across groups but do not change much over time. The LM test rejects the null hypothesis in any case at the 5 percent level of 
significance, and therefore suggests the presence of random effects. The Hausman test on the group effects equations shows different results. In the regressions on GDP per capita, GDP, population and per capita government expenditure on education the random effect specification is preferred, while in the regressions on average wage, educational attainment, per capita government expenditure on transport and communications, and per capita landline telephones, the fixed effect specification is appropriated. As the distance variables are time-invariant, when we conduct the regressions on these variables only the OLS equations and the RE specifications with group effects are performed; the regression with the FE specification are not carried out because the coefficients of any variable with a within-standard deviation of zero are not well identified under this specification.

The regressions presented in table 1 yield the following results: From the variables on income, FDI per capita is highly elastic to the GDP per capita; 1 percent increase in the average income leads to a 3.84 percent up turn on the dependent variable, whereas the coefficient on the average wage is positive although not significant. The coefficients on the market size variables are both positive and significant; an upturn of 1 percent on GDP or population raises the FDI indicator by 2.04 percent and 1.29 percent respectively. In terms of human capital formation we observe that the per capita of government expenditure on education is positive but not significant, the educational attainment variable is positive and significant and it has the most elastic effect on the dependent variable; an increase of 1 percent on this variable raises FDI by 6.72 percent. As for the infrastructure variables, the per capita of government expenditure on transport and communications and the per capita of landline telephones are both positive but only the latter is significant, 1 percent increase in the per capita of landline telephones leads to a 1.21 percent upturn on the dependent variable.

Finally, the geographical location variables are both negative, the variable on the distance to Mexico City is significant only in the OLS model, while the variable on the distance to the US border is significant in both the random effects and the OLS models, at one percent reduction in the distance to the US border FDI increases by 2.09 percent. 
Table 1

Determinants of foreign direct investment

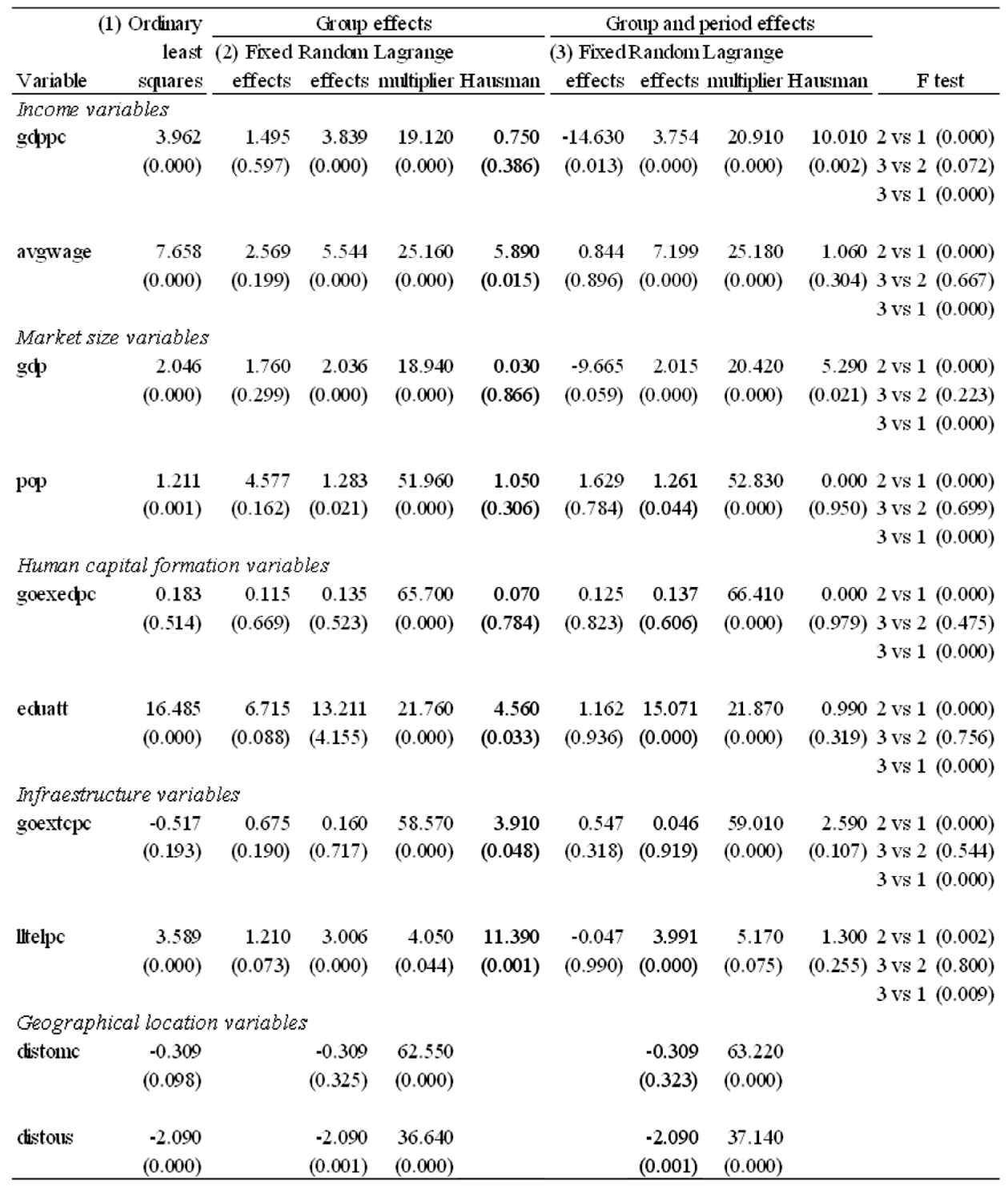

Notes: The dependent variable is FDI per capita, $p$ values in parenthesis, all the variables are expressed in logs 
In order to test the robustness of the explanatory variables we conduct regressions that include the most significant determinants of FDI from the five sets of geographical and economic variables. Except for the market size set, we take population, which is less significant than GDP, to avoid multicollinearity between GDP and GDP per capita. The first regressions, presented in table 2, do not include the time-invariant variables (distance to the US border and distance to Mexico City), so that we can perform the five different specifications, as before.

Table 2

Determinants of foreign direct investment (multi-variable equations)

\begin{tabular}{|c|c|c|c|c|c|c|c|c|c|c|}
\hline \multirow[b]{2}{*}{ Variable } & $\begin{array}{r}\text { (1) Ordinary } \\
\text { least }\end{array}$ & \multicolumn{4}{|c|}{ Group effects } & \multicolumn{4}{|c|}{ Group and period effects } & \multirow[b]{2}{*}{$\mathrm{F}$ test } \\
\hline & $\begin{array}{r}\text { least } \\
\text { squares }\end{array}$ & $\begin{array}{l}\text { (2) Fixed } \\
\text { effects }\end{array}$ & $\begin{array}{l}\text { Random I } \\
\text { effects }\end{array}$ & $\begin{array}{l}\text { Lagrange } \\
\text { multiplier }\end{array}$ & Hausman & $\begin{array}{l}\text { (3) Fixed } \\
\text { effects }\end{array}$ & $\begin{array}{r}\text { Random } \\
\text { effects }\end{array}$ & $\begin{array}{l}\text { Lagrange } \\
\text { multiplier }\end{array}$ & Hausman & \\
\hline \multirow{3}{*}{ gdppc } & 2.037 & -7.329 & 2.246 & 0.290 & 11.190 & -16.353 & -3.511 & 0.290 & 6.350 & 2 vs $1(0.057)$ \\
\hline & $(0.023)$ & $(0.144)$ & $(0.025)$ & $(0.591)$ & $(0.024)$ & $(0.011)$ & $(0.358)$ & $(0.865)$ & $(0.175)$ & 3 vs $2(0.288)$ \\
\hline & & & & & & & & & & 3 vs $1(0.068)$ \\
\hline \multirow[t]{2}{*}{ pop } & 1.284 & 0.804 & 1.294 & & & -3.850 & 0.894 & & & \\
\hline & $(0.000)$ & $(0.873)$ & $(0.001)$ & & & $(0.554)$ & $(0.660)$ & & & \\
\hline \multirow[t]{2}{*}{ eduat } & 2.822 & 3.913 & 2.804 & & & -6.715 & 2.514 & & & \\
\hline & $(0.513)$ & $(0.625)$ & $(0.557)$ & & & $(0.682)$ & $(0.847)$ & & & \\
\hline \multirow[t]{2}{*}{ litelpc } & 1.816 & 2.114 & 1.480 & & & 0.966 & 2.412 & & & \\
\hline & $(0.055)$ & $(0.263)$ & $(0.144)$ & & & $(0.813)$ & $(0.393)$ & & & \\
\hline
\end{tabular}

Notes: The dependent variable is FDI per capita, $p$ values in parenthesis, all the variables are expressed in logs

The LM test is unable to reject the null hypothesis $H_{0}: \sigma^{2}=0$ in both specifications with group effects and group and period effects and therefore, the classical (pooled) regression model with a single constant $\left(\alpha_{i}=\alpha\right)$ is appropriate. In addition, the $F$ test does not to reject the null hypothesis $H_{0}$ : the unrestricted regression is appropriate, at the five per cent level of significance, when comparing equations 2 and 3 versus 1 . Consequently, the OLS specification is the most convenient in this case.

From table 2 we observe that GDP per capita, population and per capita landline telephones are positive and statistically significant and, they have an elastic effect on FDI. Only the educational attainment variable is not significant at any conventional level. This result suggests that the effect of education on FDI is rather created through the level of development in a region, represented in this equation by GDP per capita or infrastructure (per capita landline telephones), as education is strongly associated to these variables. 
Table 3

Determinants of foreign direct investment (OLS multi-variable equation, including time-invariant variables)

\begin{tabular}{lr}
\hline & $\begin{array}{r}\text { (1) Ordinary } \\
\text { least } \\
\text { Variable }\end{array}$ \\
\hline gdppc & 1.779 \\
& $(0.050)$ \\
pop & 1.200 \\
& $(0.002)$ \\
eduat & 1.143 \\
& $(0.804)$ \\
lltelpc & 1.884 \\
& $(0.048)$ \\
distomc & 0.025 \\
& $(0.905)$ \\
distous & -0.809 \\
& $(0.083)$ \\
\hline
\end{tabular}

Notes: The dependent variable is FDI per capita, $p$ values in parenthesis, all the variables are expressed in logs

Taking into account that the preferred equation in table 2 is the OLS specification, we add to this equation the geographical location variables. The results are reported in table 3 . We did not incorporate these time-invariant variables in the previous exercise, which compares five different specifications, because their coefficients, with a standard deviation of zero, are not well identified under the FE specification, as commented before. 
The results in table 3 are similar to those reported in the OLS specification in table 2 . The GDP per capita, population and the per capita of landline telephones variables are positive and significant and they have an elastic effect on FDI. We can also see that the magnitude of the coefficients do not differ much in both equations. As for the geographical location variables, only distance to the US border is negative and significant, and it confirms that from the two geographical location variables, distance to the US is more robust, as shown in table 1.

\section{The effect of FDI on income inequality within regions}

In this section we first studied the effect of FDI on income inequality within regions, excluding control variable. The results, reported in Panel 1 of table 4, indicate that FDI investment does not have a significant effect on the Gini coefficients ${ }^{2}$ of the federal entities in any of the five specifications.

The regressions reported in Panel 2 include the determinants of FDI that were used in table 2. These control variables are incorporated in the equation to isolate the effect of FDI. The geographical location variables are not added in this exercise for the previously explained reason.

According to the LM test, the classical (pooled) regression model with a single constant $\left(\alpha_{i}=\alpha\right)$ is appropriate, because the test is unable to reject the null hypothesis $H_{0}: \sigma^{2}{ }_{u}=0$ in both specifications with group effects and group and period effects. Furthermore, when comparing equations 2 and 3 versus 1, the $F$ test does not reject the null hypothesis $H_{0}$ : the unrestricted regression is appropriate, at the five per cent level of significance and hence, the OLS specification is the preferred equation.

${ }^{2}$ Calculated Gini Coefficients are given in appendix 1. 
Table 4

The effect of FDI on the Gini coefficient (single-variable and multi-variable equations)

\begin{tabular}{|c|c|c|c|c|c|c|c|c|c|c|}
\hline \multirow{3}{*}{$\begin{array}{l}\text { Variable } \\
\text { fdipc } \\
\text { (1) }\end{array}$} & \multirow{2}{*}{$\begin{array}{r}\text { (1) Ordinary } \\
\text { least } \\
\text { squares }\end{array}$} & \multicolumn{4}{|c|}{ Group effects } & \multicolumn{4}{|c|}{ Group and period effects } & \multirow[b]{2}{*}{$F$ test } \\
\hline & & $\begin{array}{l}\text { (2) Fixed } \\
\text { effects }\end{array}$ & $\begin{array}{l}\text { Random I } \\
\text { effects }\end{array}$ & $\begin{array}{l}\text { Lagrange } \\
\text { multiplier }\end{array}$ & Hausman & $\begin{array}{l}\text { (3) Fined } \\
\text { effects }\end{array}$ & $\begin{array}{l}\text { Random I } \\
\text { effects }\end{array}$ & $\begin{array}{l}\text { Lagrange } \\
\text { multiplier }\end{array}$ & Hausman & \\
\hline & $\begin{array}{c}-0.002 \\
(0.225)\end{array}$ & $\begin{array}{r}0.000 \\
(0.840)\end{array}$ & $\begin{array}{r}-0.001 \\
(0.439)\end{array}$ & $\begin{array}{r}13.290 \\
(0.000)\end{array}$ & $\begin{array}{r}0.930 \\
(0.336)\end{array}$ & $\begin{array}{r}-0.001 \\
(0.737)\end{array}$ & $\begin{array}{r}-0.002 \\
(0.371)\end{array}$ & $\begin{array}{r}15.670 \\
(0.000)\end{array}$ & $\begin{array}{r}0.730 \\
(0.394)\end{array}$ & $\begin{array}{l}2 \operatorname{vs} 1(0.001) \\
3 \text { vs } 2(0.022) \\
3 \text { vs } 1(0.000)\end{array}$ \\
\hline $\begin{array}{l}\text { fdipc } \\
\text { (2) }\end{array}$ & $\begin{array}{c}-0.001 \\
(0.663)\end{array}$ & $\begin{array}{r}0.000 \\
(0.974)\end{array}$ & $\begin{array}{r}-0.001 \\
(0.685)\end{array}$ & $\begin{array}{r}0.150 \\
(0.697)\end{array}$ & $\begin{array}{r}5.780 \\
(0.328)\end{array}$ & $\begin{array}{l}-0.000 \\
(0.921)\end{array}$ & $\begin{array}{r}-0.001 \\
(0.644)\end{array}$ & $\begin{array}{r}3.020 \\
(0.221)\end{array}$ & $\begin{array}{r}6.420 \\
(0.267)\end{array}$ & $\begin{array}{l}2 \text { vs } 1(0.172) \\
3 \text { vs } 2(0.005) \\
3 \text { vs } 1(0.050)\end{array}$ \\
\hline gctppc & $\begin{array}{r}0.034 \\
(0.202)\end{array}$ & $\begin{array}{r}0.106 \\
(0.486)\end{array}$ & $\begin{array}{r}0.031 \\
(0.286)\end{array}$ & & & $\begin{array}{r}0.247 \\
(0.197)\end{array}$ & $\begin{array}{r}-0.014 \\
(0.893)\end{array}$ & & & \\
\hline pop & $\begin{array}{r}0.040 \\
(0.000)\end{array}$ & $\begin{array}{r}-0.135 \\
(0.376)\end{array}$ & $\begin{array}{r}0.039 \\
(0.000)\end{array}$ & & & $\begin{array}{r}0.084 \\
(0.659)\end{array}$ & $\begin{array}{r}0.026 \\
(0.602)\end{array}$ & & & \\
\hline eduat & $\begin{array}{r}0.155 \\
(0.229)\end{array}$ & $\begin{array}{r}0.017 \\
(0.944)\end{array}$ & $\begin{array}{r}0.145 \\
(0.288)\end{array}$ & & & $\begin{array}{r}0.793 \\
(0.099)\end{array}$ & $\begin{array}{r}0.421 \\
(0.288)\end{array}$ & & & \\
\hline litelpc & $\begin{array}{r}-0.095 \\
(0.001)\end{array}$ & $\begin{array}{r}-0.030 \\
(0.598)\end{array}$ & $\begin{array}{r}-0.089 \\
(0.003)\end{array}$ & & & $\begin{array}{r}0.100 \\
(0.404)\end{array}$ & $\begin{array}{r}-0.022 \\
(0.813)\end{array}$ & & & \\
\hline
\end{tabular}

Notes: The dependent variable is the Gini coefficient, $p$ values in parenthesis, all the variables are expressed in logs

FDI remains non significant. The population variable is positive and significant, which indicates that the larger the population is within a federal entity, the more unequal the federal entity tends to be. The per capita of landline telephones variable is negative and significant; this result suggests that infrastructure contributes to improve income distribution within regions. GDP per capita and educational attainment do not have explanatory power in this exercise.

Table 5 shows the OLS specification including geographical location variables. As in the regressions in table 2, the time-invariant variables were not incorporated in the equations in table 4, because their coefficients have a standard deviation of zero and are not well identified under the FE specification. 
Table 5

The effect of FDI on the Gini coefficient

(OLS multi-variable equation, including time-invariant variables)

\begin{tabular}{|c|c|}
\hline Variable & $\begin{array}{r}\text { Ordinary } \\
\text { least } \\
\text { squares }\end{array}$ \\
\hline fdi & $\begin{array}{l}-0.000 \\
(0.906)\end{array}$ \\
\hline gdppe & $\begin{array}{r}0.043 \\
(0.111)\end{array}$ \\
\hline pop & $\begin{array}{r}0.045 \\
(0.000)\end{array}$ \\
\hline eduat & $\begin{array}{r}0.231 \\
(0.092)\end{array}$ \\
\hline lltelpe & $\begin{array}{r}-0.100 \\
(0.001)\end{array}$ \\
\hline distome & $\begin{array}{r}0.002 \\
(0.741)\end{array}$ \\
\hline distous & $\begin{array}{r}0.031 \\
(0.026)\end{array}$ \\
\hline
\end{tabular}

Notes: The dependent variable is the Gini coefficient, $p$ values in parenthesis, all the variables are expressed in logs.

The results reported in table 5 do not differ much from those reported in the OLS specification in Panel 2 of table 4. The GDP per capita and FDI variables remain non significant. The population and per- capita- landline- telephones variables remain significant, keep the same sign and the magnitude of the coefficients is similar in both equations. It is worth noting that the variable on education is now positive and significant at the 10- per- cent level, which suggests that as the population, in average, gets more educated, income dispersion tends to increase. From the two geographical location variables, distance to the US is positive and is the only significant; this result implies that the closer the federal entities are to the northern borderline the more unequal they tend to be. 


\section{The effect of FDI on income inequality between regions}

Firstly we conduct regression upon five different specifications, excluding control variables, to test the effect of FDI on income dispersion between regions. The outcome is reported in Panel 1 of table 6 . The $F$ test rejects the null hypothesis, $H_{0}$ : the unrestricted regression is appropriate, in the three cases and, therefore, it indicates that it is convenient to include time and group effects in the model. Moreover, the LM test rejects the hypothesis that individual-specific and time series error variance are cero, which suggests that we need to turn to panel data models. After comparing the coefficient estimates from the RE model to those from the FE model by applying the Hausman test, we observe that the FE model is more convenient in both group effects and group and period effects specifications. Hence, the FE model with group and period effects is more appropriate from the five regressions. In this case, it is possible to see that the FDI variable is positive and significant at the 10 per cent level, in other words, FDI is associated to income dispersion across regions.

In the second panel we incorporate the control variables used previously, except the geographical location variables, because their coefficients are not well identified in the FE model. As in Panel 1, in this case the FE model with group and period effects is the preferred specification. The four control variables are significant; population, educational attainment and landline telephones have positive sign, while GDP per capita has negative coefficient. This result implies that infrastructure and education are not well distributed across regions because they tend to create inequality between them; in addition, the larger the population is the more unequal is the distribution of income across federal entities. On the other hand, the result suggests that the growth of GDP per capita has a redistributive impact on income across regions. It should be added that FDI is no longer significant in Panel 2. To this respect, we can say that the distribution of income across regions in Mexico is not directly affected by FDI, it is rather affected by other variables such as population, education, infrastructure or average income, which can also be determinants of foreign direct investment. 
Table 6

The effect of FDI on the Gini coefficient (single-variable and multi-variable equations)

\begin{tabular}{|c|c|c|c|c|c|c|c|c|c|c|}
\hline \multirow[b]{2}{*}{ Variable } & \multirow{2}{*}{$\begin{array}{r}\text { (1) Ordinary } \\
\text { least } \\
\text { squares }\end{array}$} & \multicolumn{4}{|c|}{ Group effects } & \multicolumn{4}{|c|}{ Group and period effects } & \multirow[b]{2}{*}{ F test } \\
\hline & & $\begin{array}{l}\text { (2) Fixed } \\
\text { effects }\end{array}$ & $\begin{array}{c}\text { Random } \\
\text { effects }\end{array}$ & $\begin{array}{l}\text { Lagrange } \\
\text { multiplier }\end{array}$ & Hausman & $\begin{array}{l}\text { (3) Fixed } \\
\text { effects }\end{array}$ & $\begin{array}{l}\text { Random I } \\
\text { effects }\end{array}$ & $\begin{array}{l}\text { Lagrange } \\
\text { multiplier }\end{array}$ & Hausman & \\
\hline \multirow[t]{3}{*}{ fdi } & -0.017 & 0.004 & 0.003 & 427.470 & 8.610 & 0.002 & 0.002 & 437.740 & 9.700 & 2 vs $1(0.000)$ \\
\hline & $(0.000)$ & $(0.060)$ & $(0.112)$ & $(0.000)$ & $(0.003)$ & $(0.075)$ & $(0.112)$ & $(0.000)$ & $(0.002)$ & 3 vs $2(0.000)$ \\
\hline & & & & & & & & & & 3 vs $1(0.000)$ \\
\hline \multirow[t]{3}{*}{ fdi } & -0.002 & 0.001 & -0.000 & 103.850 & 71.320 & -0.000 & 0.000 & 704.670 & 42.240 & 2 vs $1(0.000)$ \\
\hline & $(0.438)$ & $(0.432)$ & $(0.812)$ & $(0.000)$ & $(0.000)$ & $(0.873)$ & $(0.904)$ & $(0.000)$ & $(0.000)$ & 3 vs $2(0.000)$ \\
\hline & & & & & & & & & & $3 \mathrm{vs} 1(0.000)$ \\
\hline \multirow[t]{2}{*}{ gdppc } & -0.873 & -0.295 & -0.787 & & & -0.865 & -0.841 & & & \\
\hline & $(0.000)$ & $(0.003)$ & $(0.000)$ & & & $(0.000)$ & $(0.000)$ & & & \\
\hline \multirow[t]{2}{*}{ pop } & -0.010 & 0.521 & 0.036 & & & 0.288 & 0.007 & & & \\
\hline & $(0.347)$ & $(0.000)$ & $(0.100)$ & & & $(0.000)$ & $(0.614)$ & & & \\
\hline \multirow[t]{2}{*}{ eduat } & 0.218 & 0.709 & 0.675 & & & 0.355 & 0.255 & & & \\
\hline & $(0.105)$ & $(0.000)$ & $(0.000)$ & & & $(0.007)$ & $(0.019)$ & & & \\
\hline \multirow[t]{2}{*}{ lltelpc } & 0.250 & 0.045 & 0.222 & & & 0.150 & 0.144 & & & \\
\hline & $(0.000)$ & $(0.222)$ & $(0.000)$ & & & $(0.000)$ & $(0.000)$ & & & \\
\hline
\end{tabular}

Notes: The dependent variable is income dispersion between regions, $p$ values in parenthesis; all the variables are expressed in logs.

\section{Conclusions}

The study shows that FDI in Mexico does not tend to flow to less developed regions or to federal entities where unskilled and cheap labour is more abundant. In this respect, there is no support for orthodox theory. On the other hand, FDI tends to flow to big markets, in terms of population, and to more developed regions with more infrastructure and higher average income. Hence, the determinants of foreign direct investment in México are consistent with the economic and geographical features or location advantages considered in the eclectic theory or OLI paradigm. Educational level is also a determinant of FDI although it is not very robust. This result suggests that investment seeks more developed regions with higher concentration of population, which are associated with higher levels of education, but education as such is not one of the main determinants of, or is not directly associated to, FDI inflows. 
Mexico City has the biggest concentration of population and the highest educational level and GDP per capita in Mexico, not surprisingly it also concentrates the largest inflow of FDI; nevertheless, the distance-to-Mexico-City variable is not robust in this study. One explanation of this is that between 2001 and 2006 the percentage of FDI inflow to this region, in relation to the national inflow, fell from 76 per cent to 56 per cent. ${ }^{3}$ In contrast, the inflow of FDI to Nuevo León and Jalisco, which are also federal entities with large population and relatively high development indicators, increased from 7 per cent to 10 per cent and from 2 per cent to 4 per cent respectively, over the same period. Hence, foreign direct investment has reduced its concentration in Mexico City and has tended to scatter in other potential markets over the last few years. On the other hand, the distance-to-theUS-border variable is significant. In relation to this, FDI in the 6 northern federal entities ${ }^{4}$ increased from 15 per cent to 28 per cent between 2001 and 2006 (INEGI, 2011), which indicates that investments in this region tend to consolidate.

With the above in mind, it can be argued that a proportion of FDI in Mexico is horizontal because it is aimed at serving the local market, that is, it tends to flow to populated areas with high purchasing power. On the other hand, another proportion of the investments can be considered vertical, because it locates close to the source country, such as the investment that flows to the northern federal entities. It should be added that this type of investment can also be attracted by the potential of the local market, considering that federal entities in the north have higher average income compared to those in the south. Consequently, FDI inflows in Mexico are diverse, tend to deconcentrate from México City, and do not belong to a single type. In this study, we do not find evidence that foreign direct investment creates inequality within regions. In this sense, the variables that explain the distribution of income within federal entities are the size of population, the educational level, the provision of infrastructure and, to some extent, the geographical location (regions in the north tend to be more unequal than those in the south are).

Foreign direct investment is associated to inequality across federal entities, because it tends to flow to more developed regions and this result undermines standard theory. It is necessary to point that this is so because FDI locates in regions with a better level of development which accentuates regions inequality. However, the

\footnotetext{
${ }^{3}$ The figures are obtained from Distrito Federal and Estado de México, because the city mainly extends across the two federal entities.

${ }^{4}$ Baja California, Sonora Chihuahua, Coahuila, Nuevo León y Tamaulipas.
} 
study shows that determinants of FDI are the main cause of regional inequality and it is not the direct effect of the flow of investments as such.

If education and large concentrations of population create inequality within and between regions, it is therefore necessary to foster policies that promote a better distribution of them across the national territory. According to the results, it is also important to promote an even distribution of infrastructure, especially across regions, because it has an adverse effect on the distribution of income between federal entities. To the extent that these variables can be distributed more evenly, the effect of economic growth on income distribution will also become more equalitarian.

Finally, we conclude that it is important to achieve a better distribution of the determinants of FDI, such as average income, population, infrastructure and, indirectly, education across federal entities, especially in the less developed regions, so that these regions can become more attractive to the flow of investments and Mexico can obtain more equalitarian effects from these flows.

\section{References}

Breusch, Trevor S. and Adrian R. Pagan (1980). The lagrange multiplier test and its applications to model specification in econometrics. The Review of Economic Studies (47): 239-254.

Chatterji, Monojit (1992). Convergence clubs and endogenous growth. Oxford Review of Economic Policy (8): 57-69.

CONAPO (2011). Indicadores demográficos básicos. Available from: http://www. conapo.gob.mx/index.php?option=com_content\&view=article\&id=125\&Itemid $=193$

CONASAMI (2011). Salario promedio cotización IMSS, entidad federativa. Available from: http://www.conasami.gob.mx/entidad_federativa.html

Dunning, John H. (1980). The location of foreign direct investment activity: an empirical analysis. Applied Economics (31): 65-76. 
(1990). Re-evaluating the benefits of foreign direct investment. Available from: http://www.unctad.org/Templates/webflyer.asp?doci$\mathrm{d}=5817$ \&intItemID=2943\&lang=l\&print=1 issn 1014-9562 .

(2001). The eclectic (OLI) paradigm of international production: past, present and future. International Journal of Economics of Business (8) 173-90.

Fenestra, Robert C. and Gordon H. Hanson (1997). Foreign direct investment and relative wages: evidence from Mexico's maquiladoras. Journal of International Economics (42): 371-93.

Geobytes, Inc. (2011). City distance tool. Available from: http://www.geobytes. com/citydistancetool.htm (accessed 3 february 2011).

Ghosh, Subhadip (2003). FDI and the relative wage in a north south global economy. Discussion Paper 03-03, Indian Statistical Institute.

Hausman, J. A. (1978). Specification test in econometrics. Econométrica (46): 1251-1271.

INEGI (1994-2011). Encuesta nacional de ingreso y gasto de los hogares.

(2011). Banco de información económica. Available from: http://dgcnesyp.inegi.org.mx/bdiesi/bdie.html

(2011a). El ingreso y el gasto público en México. Available from: http://www.inegi.org.mx/prod_serv/contenidos/espanol/catalogo/Default. asp?accion=1\&upc=702825190453 (accessed 2 february 2011).

Kaya, Ayse and James Walker (2009). Individual attitudes towards the impact of multinational enterprises on local businesses. Discussion Paper 075, Henley Business School, University of Reading.

Kojima, Kyyjoshi and T. Ozawa (1984). Micro and Macro Economic Models of Foreign Direct Investment: Towards a Synthesis. Hitotsubashi Journal of Economics (25): 1-20 
Lee, Eddy and Marco Vivarelli (2006). The social impact of globalization in developing countries. Discussion Paper 1925, The Institute for the Study of Labor.

Lipsey, Robert E. and Fredrik Sjöholm (2004). Foreign direct investment, education and wages in Indonesian manufacturing. Journal of Development Economics (73): 415-22.

Ma, Alyson C. (2006). Geographical location of foreign direct investment and wage inequality in China. World Economy (29): 1031-55.

Markusen, James R and Keith E. Maskus (1999). Discriminating among alternative theories of the multinational enterprise. NBER Working Paper No. 7164, National Bureau of Economic Research.

Mattos, Carlos de (2000). Nuevas teorías del crecimiento económico: una lectura desde la perspectiva de los territorios de la periferia. Revista de Estudios Regionales (58): 15-36.

Redding, Stephen and Anthony J. Venables (2004). Economic geography and international inequality. Journal of International Economics, (62): 53-82.

Ros, Jaime (2004). La teoría del desarrollo y la economía del crecimiento. México: Fondo de Cultura Económica y Centro de Investigación y Docencia Económica.

Secretaría de Educación Pública (2011). SisteSEP, sistema para el análisis de la estadística educativa. Available from: www.sep.gob.mx/work/appsite/sistesepUNCTAD (1998). World investment report 1998, trends and determinants. Available from: http://www.unctad.org/en/docs/wir98_en.pdf

Rodríguez-Orregia, Eduardo and Joan Costa-Font (2002). Are regional inequalities decreasing with public investment? Evidence from Mexico. EUI Working Paper No. 2002/19. Research Repository, European University Institute. 


\section{Appendix 1}

GINI coefficient (monetary current income)

\begin{tabular}{|c|c|c|c|c|c|c|c|c|}
\hline & 1992 & 1994 & 1996 & 1998 & 2000 & 2002 & 2004 & 2006 \\
\hline Aguascalientes & 0.4887 & 0.4529 & 0.4421 & 0.4327 & 0.3874 & 0.4385 & 0.4887 & 0.4561 \\
\hline Baja California & 0.4891 & 0.5694 & 0.3984 & 0.4133 & 0.4188 & 0.3687 & 0.4475 & 0.4260 \\
\hline Baja California Sur & 0.4313 & 0.4657 & 0.4717 & 0.5610 & 0.3627 & 0.3705 & 0.4233 & 0.4102 \\
\hline Campeche & 0.4663 & 0.5157 & 0.5153 & 0.5288 & 0.4778 & 0.4934 & 0.4854 & 0.5076 \\
\hline $\begin{array}{l}\text { Coahuila de } \\
\text { Zaragoza }\end{array}$ & 0.5058 & 0.5208 & 0.4609 & 0.4385 & 0.4144 & 0.3913 & 0.4800 & 0.4485 \\
\hline Colima & 0.5058 & 0.3863 & 0.3948 & 0.4612 & 0.4627 & 0.4154 & 0.4085 & 0.3971 \\
\hline Chiapas & 0.5238 & 0.4208 & 0.4081 & 0.5458 & 0.5517 & 0.4960 & 0.4978 & 0.5364 \\
\hline Chihuahua & 0.4418 & 0.4027 & 0.4538 & 0.4503 & 0.3851 & 0.4555 & 0.4546 & 0.4785 \\
\hline Distrito Federal & 0.4597 & 0.5122 & 0.4760 & 0.5054 & 0.5052 & 0.4919 & 0.5078 & 0.4911 \\
\hline Durango & 0.5775 & 0.4510 & 0.4272 & 0.5402 & 0.4357 & 0.4548 & 0.5231 & 0.4359 \\
\hline Guanajuato & 0.4720 & 0.4341 & 0.4545 & 0.4801 & 0.5744 & 0.4321 & 0.4805 & 0.4851 \\
\hline Guerrero & 0.5539 & 0.5005 & 0.5682 & 0.5103 & 0.5543 & 0.5098 & 0.4621 & 0.4636 \\
\hline Hidalgo & 0.4469 & 0.4448 & 0.5013 & 0.5508 & 0.4830 & 0.4830 & 0.5480 & 0.5051 \\
\hline Jalisco & 0.4440 & 0.4397 & 0.4574 & 0.5018 & 0.3941 & 0.5193 & 0.4277 & 0.4391 \\
\hline Estado de México & 0.5207 & 0.5625 & 0.4584 & 0.4950 & 0.5022 & 0.4432 & 0.4419 & 0.4535 \\
\hline $\begin{array}{l}\text { Michoacán de } \\
\text { Ocampo }\end{array}$ & 0.6385 & 0.3897 & 0.4993 & 0.5335 & 0.4686 & 0.3804 & 0.4286 & 0.4766 \\
\hline Morelos & 0.4524 & 0.4323 & 0.4588 & 0.4807 & 0.5301 & 0.4038 & 0.4286 & 0.4342 \\
\hline Nayarit & 0.4398 & 0.4199 & 0.4908 & 0.4237 & 0.4487 & 0.4358 & 0.4675 & 0.5574 \\
\hline Nuevo León & 0.5769 & 0.4878 & 0.4686 & 0.4870 & 0.4084 & 0.4631 & 0.4569 & 0.4291 \\
\hline Oaxaca & 0.4684 & 0.5902 & 0.5357 & 0.4872 & 0.5535 & 0.4808 & 0.5193 & 0.5170 \\
\hline Puebla & 0.6304 & 0.4848 & 0.4544 & 0.5049 & 0.4958 & 0.4966 & 0.4532 & 0.4542 \\
\hline Querétaro & 0.4494 & 0.4386 & 0.4646 & 0.4509 & 0.5988 & 0.4527 & 0.4778 & 0.4385 \\
\hline Quintana Roo & 0.4030 & 0.4097 & 0.4758 & 0.4216 & 0.4650 & 0.3972 & 0.4571 & 0.4207 \\
\hline San Luis Potosí & 0.4467 & 0.5599 & 0.4317 & 0.5759 & 0.4165 & 0.4730 & 0.4527 & 0.4957 \\
\hline Sinaloa & 0.4846 & 0.5129 & 0.6768 & 0.4602 & 0.4630 & 0.4396 & 0.5309 & 0.4635 \\
\hline Sonora & 0.4603 & 0.4496 & 0.4344 & 0.5121 & 0.5199 & 0.4424 & 0.4431 & 0.4892 \\
\hline Tabasco & 0.5687 & 0.5359 & 0.5212 & 0.4552 & 0.4836 & 0.4807 & 0.5055 & 0.5085 \\
\hline Tamaulipas & 0.4553 & 0.4497 & 0.5303 & 0.6566 & 0.3951 & 0.4585 & 0.4759 & 0.4643 \\
\hline Tlaxcala & 0.4240 & 0.3608 & 0.4185 & 0.4224 & 0.4181 & 0.4038 & 0.6702 & 0.3589 \\
\hline $\begin{array}{l}\text { Veracruz de } \\
\text { Ignacio de la Llave }\end{array}$ & 0.4901 & 0.5613 & 0.4945 & 0.4822 & 0.4742 & 0.4973 & 0.4777 & 0.4868 \\
\hline Yucatán & 0.4364 & 0.5344 & 0.5930 & 0.4588 & 0.5566 & 0.3697 & 0.4689 & 0.4826 \\
\hline Zacatecas & 0.5276 & 0.4742 & 0.4534 & 0.4747 & 0.4645 & 0.4634 & 0.4400 & 0.4837 \\
\hline
\end{tabular}

* Ingresos ordenados de acuerdo al ingreso corriente monetario 